\title{
Total Phenolic Contents, Quercetin Determination and Anti Elastase Activity of Melastoma malabathricum L. Leaves Extract from Different Method of Extractions
}

\author{
Thia Amalia ${ }^{1}$, Fadlina Chany Saputri ${ }^{2 *}$, Silvia Surini ${ }^{3}$
}

\section{Thia Amalia' ${ }^{1}$, Fadlina Chany Saputri ${ }^{2 *}$, Silvia Surini ${ }^{3}$}

'Graduate Programme of Herbal Medicine, Faculty of Pharmacy, Universitas Indonesia, Kampus UI Depok, 16424, West Java, INDONESIA. ${ }^{2}$ Department of Pharmacology, Faculty of Pharmacy, Universitas Indonesia, Kampus UI Depok, 16424, West Java, INDONESIA.

${ }^{3}$ Department of Pharmaceutics and Pharmaceutical Technology Development, Faculty of Pharmacy, Universitas Indonesia, Kampus UI Depok, 16424, West Java, INDONESIA.

Correspondence

Dr. Fadlina Chany Saputri

Department of Pharmacology, Faculty of Pharmacy, Universitas Indonesia, Kampus UI Depok, 16424, West Java, INDONESIA

Phone no : +6221 727003

E-mail: fadlina.chany@farmasi.ui.ac.id

History

- Submission Date: 08-08-2018;

- Review completed: 06-11-2018;

- Accepted Date: 23-11-2018

DOI : 10.5530/pj.2019.1.21

Article Available online

http://www.phcogj.com/v11/i1

\section{Copyright}

(c) 2019 Phcog.Net. This is an openaccess article distributed under the terms of the Creative Commons Attribution 4.0 International license.

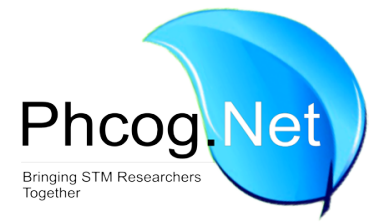

\begin{abstract}
Objective: Leaves of $M$. malabathricum has been detected to contain quercetin and other phenolic contents. Quercetin has been proven to have elastase inhibitory activity. The aim of this study was to evaluate the effects of extraction method on total phenolic and quercetin contents as well as elastase inhibitory activity of $M$. malabathricum leaves extracts. Methods: Leaves powder was extracted by two conventional methods, maceration and reflux. Two different concentrations of ethanol were used as a solvent, 70 and $96 \%$ ethanol. Leaves were also defatted with chloroform before further extraction. The total phenolic content was determined by the Folin-Ciocalteu method and quercetin content was determined by using the high-performance liquid chromatography method. Elastase inhibitor activity of leaves extract was determined on human neutrophil elastase in vitro. Results: Generally, $96 \%$ ethanol obtained higher total phenolic and quercetin content than $70 \%$ ethanol. However, defatted extract of $70 \%$ ethanol contained higher total phenolic content than defatted $96 \%$ ethanol. The highest elastase inhibitory activity of the sample was obtained from $70 \%$ ethanol extract with the value of $89.50 \%$ at $200 \mathrm{ppm}$, which is no significant difference compared to quercetin with the value of $93.86 \%$. Conclusion: Extraction methods and different concentration of solvents affect the total phenolic and quercetin contents of the extracts. $M$. malabathricum leaves have potential effect as anti-elastase as well as quercetin, where the anti-elastase activity of $M$. malabathricum leaves is not only due to quercetin.

Key words: Melastoma malabathricum L., Total phenolic content, Quercetin, Anti-Elastase, Extraction methods.
\end{abstract}

\section{INTRODUCTION}

Melastoma malabathricum L. (Melastomataceae) is a native plant in the tropical and subtropical region, especially Southeast Asian. M. malabathricum can be found throughout South and South-East Asia, China, Taiwan, Australia and the South Pacific Ocean. The plant is a small shrub that commonly growth wildly in roadside and waste land. ${ }^{1}$

Phytochemically the leaves of M. malabathricum contained amides, flavonoid, triterpenes, saponins, tannins, steroids, glycosides and phenolic compounds..$^{1-3}$ Leaves extract of M. malabathricum contained quercetin, quercitrin and kaempferol-3-O-(2',6'-di-Op-trans-kumaroyl)- $\beta$-glucoside. ${ }^{4}$ Besides that, other components also found in the leaves extracts such as 5-hydroxymethylfurfural, palmitic acid, stearic acid methyl ester, trans-squalene and tocopherol. ${ }^{5}$

M. malabathricum is an important ethnomedicine and used by tribes in Malaysia, China, India and Indonesia as traditional medicine. ${ }^{1}$ Leaves and roots were used as wound healing and prevent scarring from smallpox by
Dayak Tribe in Kalimantan, Indonesia. ${ }^{6}$ Roots were also used as a cough and asthma medicine. ${ }^{7}$ Leaves extract of M. malabathricum reported has activity as an antioxidant, hepatoprotective agent, ${ }^{3}$ antiinflammation, ${ }^{8,9}$ antinociceptive, ${ }^{10}$ antimicrobial, ${ }^{11}$ and wound healing. ${ }^{12}$

Extraction method can affect the quality and constituents of extracts. ${ }^{13}$ Thus, the extraction method and appropriate solvents need to be optimized. The aim of this study was to evaluate total phenolic contents and quercetin level of M. malabathricum leaves extracts with different extraction methods. As the plant used traditionally as wound healing, this study also evaluated elastase inhibitory activity on human neutrophil. Elastase is one of neutrophilderived protease that plays role in wound healing, but excessive production of this protease caused damage to tissue in wound healing process. ${ }^{14}$ Thus, an inhibitor of elastase is needed to restore elastase-anti elastase imbalance. ${ }^{15}$

Cite this article: Amalia T, Saputri FC, Surini S. Total Phenolic Contents, Quercetin Determination and Anti Elastase Activity of Melastoma malabathricum L. Leaves Extract from Different Method of Extractions. Pharmacog J. 2019;11(1):124-8. 


\section{MATERIALS AND METHODS}

\section{Chemicals}

Ethanol and chloroform used for extraction were purchased from Brataco, Indonesia. Methanol, acetonitrile and acetic acid (HPLC grade) and also ethanol (analytical grade) were purchased from Merck, Germany. Quercetin (certified reference material) and gallic acid were purchased from Sigma Aldrich, Singapore. Elastase inhibitor screening kit was obtained from Abcam, Cambridge, UK.

\section{Plant materials and Preparations of Leaves Extracts}

Melastoma malabathricum L. leaves were collected from Samboja, Kutai Kertanegara, East Kalimantan, Indonesia. The leaves were identified in Indonesian Institute of Science, Bogor, West Java, Indonesia. The leaves were air dried under a black cloth to prevent direct sunlight. The dried leaves were grounded with an electric grinder. The powder was then extracted with $70 \%$ and $96 \%$ ethanol by maceration and reflux method according to methods below.

\section{Maceration}

Four portions of powdered leaves ( $25 \mathrm{~g}$ each) were prepared. Two portions were pre-extracted with chloroform $(1: 10 \mathrm{w} / \mathrm{v}, 3 \times 24 \mathrm{~h})$ to obtain chloroform extracts (MCh). These two portions were next separately macerated with $70 \%$ and $96 \%(\mathrm{v} / \mathrm{v})$ ethanol $(1: 10 \mathrm{w} / \mathrm{v}, 3 \times 24 \mathrm{~h})$ to obtain defatted macerated ethanol extracts (70MChE and 96MChE, respectively). Two another portions were macerated separately with the same proportions solvent to obtained crude macerated ethanol extract (70ME and 96ME).

\section{Reflux}

Powdered leaves were sampled duplo (25 g each). Two samples were separately refluxed triply with $70 \%$ and $96 \%(\mathrm{v} / \mathrm{v})$ aqueous ethanol (1:10 $\mathrm{w} / \mathrm{v}, 2 \mathrm{~h}$ ) to give crude refluxed ethanol extract (70RE and 96RE).

\section{Determination of percentage yield (\%)}

The organic solvent was evaporated from the extracts using a vacuum rotary evaporator (Buchi Rotavapor R-100, Japan). The extracts dried in the oven under vacuum $\left(50^{\circ} \mathrm{C}\right)$. The dry weight of each extract and sample powders were used to calculate percentage yield of the extract by the formula:

$$
\text { Yield of extraction }\left(\% \frac{\mathrm{w}}{\mathrm{w}}\right)=\frac{\text { (weight of dried extract) }}{\text { (weight of sample powder }} \times 100
$$

\section{Determination of total phenolic content (TPC)}

The total phenolic contents (TPC) was determined according to the Folin-Ciocalteu method using microplate reader. ${ }^{16}$ Sample $(25 \mu \mathrm{L})$ and $25 \%$ Folin-Ciocalteu $(100 \mu \mathrm{L})$ were pipetted to flat bottom 96-well microplate (Nunc, Denmark) and were homogenized with a shaker for $60 \mathrm{sec}$ and left for $4 \mathrm{~min}$ at room temperature in the dark. Then $75 \mu \mathrm{L}$ sodium carbonate solutions were added and shaken for $60 \mathrm{sec}$. The mixture then incubated for $2 \mathrm{~h}$ at room temperature in the dark. Absorbance was measured at $750 \mathrm{~nm}$ wavelength using microplate reader (Versamax ${ }^{\mathrm{TM}}$ ELISA Microplate Reader, USA). Gallic acid stock solution with concentration $100,50,25,12.5$ and $6.25 \mathrm{ppm}$ was used to the obtained calibration curve. The TPCs of the extracts were calculated from the absorbance of the sample and calibration curve. The TPCs were expressed as mg gallic acid equivalents (GAE) per g dry weight of the extracts (mg GAE/g DW extracts).

\section{Determination of quercetin content}

Quercetin contents of the extracts determined by high performance liquid chromatography (HPLC) method adapted from Ang et al. (2014) with slight modification. ${ }^{17}$ HPLC analysis was performed using Shimadzu LC-20AD (Japan) and reversed phase column packed Hypersil Gold C18, 150x4.6 (mm) with $5 \mu \mathrm{m}$ diameter particles. The mobile phase consists of acetonitrile-2\% acetate acid (40:60, v/v) was filtered through a $0,45 \mu \mathrm{m}$ nylon membrane filter (Whatmann) and degassed ultrasonically for $10 \mathrm{~min}$ prior to use. The dry weights extracts $(20 \mathrm{mg})$ were diluted accurately in $5 \mathrm{~mL}$ methanol HPLC. The samples were filtered through a PVDF syringe filter ( $25 \mathrm{~mm}, 0.45 \mu \mathrm{m}$, Agilent) before injection. An injection volume of the samples was $20 \mu \mathrm{L}$, the flow rate was $1 \mathrm{~mL} / \mathrm{min}$ and detection was done at $370 \mathrm{~nm}$ using a diode array detector. Quercetin content of the extract was determined by plotting the area of the peaks with a calibration curve of the standards. Calibration curves were established by plotting of the areas of peaks against eight concentration of quercetin standards $(500-3.90625 \mu \mathrm{g} / \mathrm{mL})$.

\section{Anti elastase activity in vitro assay}

Neutrophil elastase (NE) inhibitor activity assay was performed according to the protocol provided in the kit. Briefly, $200 \mathrm{ppm}$ of each extract were prepared as sample tests and quercetin standard was prepared as a control. A $50 \mu \mathrm{L}$ diluted NE solution and a $25 \mu \mathrm{L}$ sample tests were mixed in 96-well black microplate (Thermo) and incubated at $37^{\circ} \mathrm{C}$ for $5 \mathrm{~min}$. A $25 \mu \mathrm{L}$ assay buffer was used in enzyme control well. After that, $25 \mu \mathrm{L}$ substrate was mixed to each sample. The plate was measured in a fluorometric microplate reader (Glomax) at Ex/Em 400/505 nm (R1). Then, the plate was incubated at $37^{\circ} \mathrm{C}$ for 30 mins protected from light and measured again at Ex/Em 400/505 nm (R2). Relative activity of each sample test was calculated as:

$$
\text { Inhibition activity }(\%)=\frac{(\Delta \mathrm{R} \text { sample test })}{(\Delta \mathrm{R} \text { enzyme control })} \times 100
$$

\section{Statistical analysis}

Results were reported as means \pm standard deviation (SD). The statistics (one-way analysis of variances, HSD Tukey's tests and Pearson correlation) were performed using SPSS (IBM Statistics) with a 0.05 .

\section{RESULTS}

\section{Percentage yield of extract}

The results showed that yield of extraction with $70 \%$ ethanol was higher than extraction with $96 \%$ ethanol. The refluxed extract was also showed a higher percentage of yield than macerated extract in both solvents. The highest percentage of yield was 70RE, followed by 70MChE, 70ME, 96RE, $96 \mathrm{ME}$ and $96 \mathrm{MChE}$. The result of the percentage yield is given in Figure 1.

\section{Total Phenolic Content}

The results of TPC are shown in Table 1. The crude extract showed that $96 \%$ ethanol resulted in higher TPC value than $70 \%$ ethanol in two extraction method. However, after defatted, 70MChE gave the highest TPC with the value of $222.85 \mathrm{mg}$ GAE/g.

\section{Determination of Quercetin}

The chromatogram of quercetin standard and M. malabathricum leave extract are shown in Figure 2. The result of the quercetin content of the extracts is given in Table 1. Extraction methods (maceration and reflux) did not affect quercetin content in the extracts. However, the $96 \%$ ethanol 


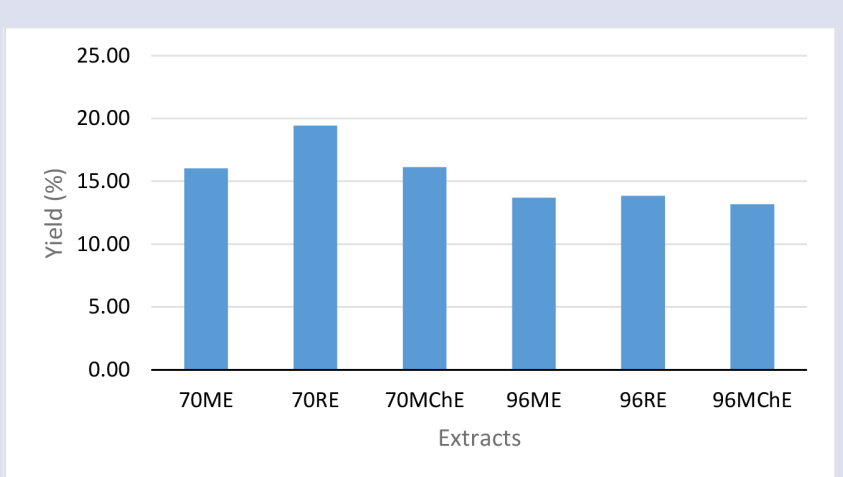

Figure 1: Percentage of yield [Extract code: crude ethanol extract from maceration (70ME and 96ME), defatted ethanol extracts from maceration method (70MChE and 96MChE), crude ethanol extract from reflux (70RE and 96RE)].

Table 1: Total Phenolic and quercetin contents of $M$. malabathricum leave extracts from different extraction methods.

\begin{tabular}{ccc}
\hline Sample & $\begin{array}{c}\text { Total Phenolic Content } \\
(\mathrm{mg} \text { GAE/g) }\end{array}$ & \% Quercetin $(\mathrm{w} / \mathrm{w})$ \\
\hline $70 \mathrm{ME}$ & $167.43 \pm 15.34$ & $0,430 \pm 0,041$ \\
$70 \mathrm{RE}$ & $145.80 \pm 8.68$ & $0,439 \pm 0,070$ \\
$70 \mathrm{MChE}$ & $222.85 \pm 10.81$ & $0,358 \pm 0,010$ \\
$96 \mathrm{ME}$ & $171.09 \pm 3.19$ & $0,877 \pm 0,034$ \\
$96 \mathrm{RE}$ & $212.95 \pm 4.37$ & $0,861 \pm 0,036$ \\
$96 \mathrm{MChE}$ & $216.50 \pm 1.80$ & $0,873 \pm 0,027$ \\
\hline
\end{tabular}

extract from both extraction method (96ME and 96RE) is contained quercetin higher than $70 \%$ ethanol extract (70ME and 70RE). Beside that, defatted process did not influence the quercetin content in the extract.

\section{Anti-elastase activity}

Each extract at a concentration of 200 ppm was used as a sample test. The result of the anti-elastase activity of the extracts are given in Table 2. The $70 \%$ ethanol extracts have slightly less activity than $96 \%$ ethanol extracts from both methods except reflux, but not significantly different $(p>0.05)$. The result showed that the highest inhibition was from 70RE which also significantly different with 70ME and 70MChE. Inhibition of elastase activity of quercetin was higher than the extracts. Statistical analysis showed that anti-elastase activity of 70ME, 70MChE, 96ME, 96RE and 96MChE are significantly different from quercetin $(p<0.05)$.

\section{DISCUSSION}

The quality and phytoconstituents of extracts are influenced by factors such as extraction methods, the solvent used for extraction and solvent ratio. Therefore this study used two conventional extraction methods, maceration and reflux. The yield of extraction from the reflux method was higher than maceration in this study. This is similar to the previous study in which heating increase the yield of Raphanus sativus leaves extract. ${ }^{13}$

The solvent used in this study was $70 \%$ and $96 \%$ aqueous ethanol because ethanol was a universal solvent which can extract many constituents, such as polar compounds (amino acid, glycoside compounds), polar phenolic

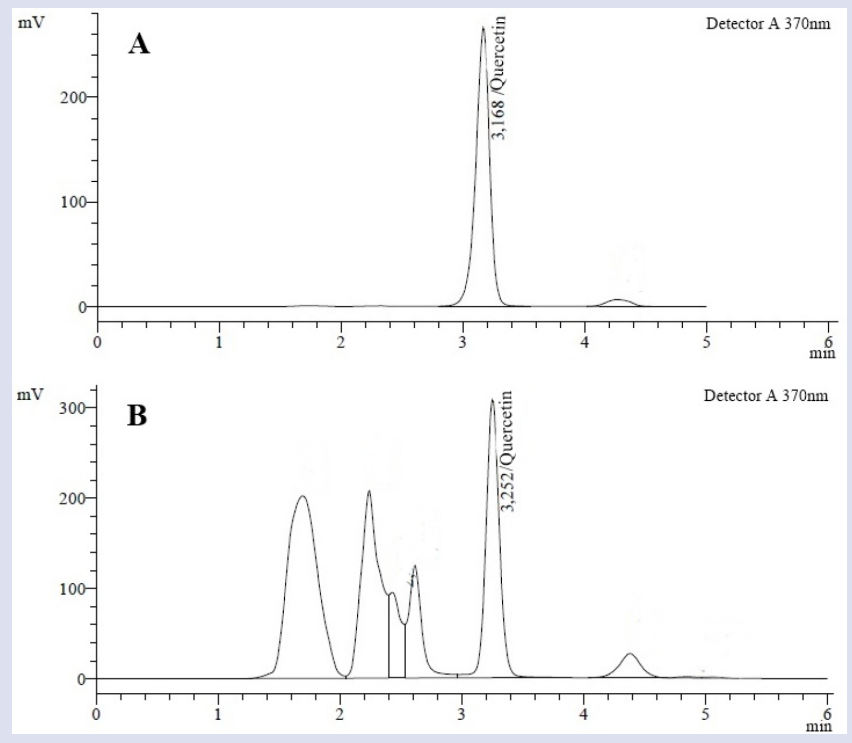

Figure 2: Chromatogram of quercetin standard (A) and M. malabathricum leave extract (B).

Table 2: Anti-elastase activity of M. malabathricum leaves extracts from different extraction methods.

\begin{tabular}{cc}
\hline Samples & Elastase inhibition (\%) \\
\hline Quercetin & $93.86 \pm 0.79$ \\
$70 \mathrm{ME}$ & $81.98 \pm 0.21^{*}$ \\
$70 \mathrm{RE}$ & $89.50 \pm 1.53$ \\
$70 \mathrm{MChE}$ & $82.18 \pm 0.38^{*}$ \\
$96 \mathrm{ME}$ & $84.79 \pm 0.63^{*}$ \\
$96 \mathrm{RE}$ & $84.27 \pm 2.50^{*}$ \\
$96 \mathrm{MChE}$ & $85.29 \pm 1.14^{*}$
\end{tabular}

*Significantly difference compare to quercetin $(p<0.05)$.

compounds, aglycon flavonoids, anthocyanin, terpenoid, saponin, tannin and polyphenol. ${ }^{18}$ Ethanol was also can extract quercetin with a threefold yield higher than ethyl acetate and hexane. ${ }^{19}$

Phenolic is semi-polar compound. The total phenolic content of M. malabathricum in this study was tending to soluble in the semi-polar solvent, which $96 \%$ ethanol extract has higher TPC than $70 \%$ ethanol extract. Other study showed that aqueous semi-polar organic solvents are best to extracted flavonoid and phenolic contents of clove bud. ${ }^{20}$ Phenol contents of tropical seagrass were also soluble in polar and semi-polar solvent. ${ }^{21}$ Aqueous methanol (50\% and 75\% v/v) also had the highest TPC of Gaultheria procumbens leaves extracts. ${ }^{22}$

Generally, 96\% ethanol can extract the quercetin stronger than $70 \%$ ethanol. Where, the highest quercetin level of M. malabathricum leaves resulted from 96MChE. Quercetin is a hydrophobic compound and soluble in the aqueous alcoholic solvent. The solubility of quercetin increase with increasing alcoholic contents. ${ }^{23}$ The result of this study was also similar to the previous study which quercetin level of the extract was optimum with $80 \%$ ethanol or higher. ${ }^{24}$

Crude extracts contained ballast contents which can interfere with physical characteristics and biological activity. Therefore, a few study 
defatted leaves and fruits powders before further extraction. ${ }^{22,25}$ In this study, defatted extract (70MChE) shows the highest TPC and the highest quercetin (90MChE). This result was similar to another study which after pre-extraction with chloroform, methanolic extracts of eastern teaberry leaves give increasing TPC level with slightly decreasing yield. ${ }^{22}$ The highest inhibitory activity on elastase is shown by the 70RE sample. The result showed that the quercetin is not the only one responsible for the anti-elastase activity. This phenomenon is strengthened by the results of the correlation analysis between quercetin and anti-elastase activity that show weak positive correlation $(\mathrm{r}=0.110)$. Previous studies showed that rutin and kaempferol contents in the leaves extracts were higher than quercetin content. ${ }^{26,27}$ There is a possibility the activity is due to these compound. The extracts also contained many compounds which can affect its biological activity including anti-elastase activity. Melzig, Pertz and Krenn (2001) stated that flavonoid, such as quercetin, hyperoside and isoquercetin, contributed to the elastase inhibition activity of Drosera madagascariensis extract. ${ }^{28}$ Quercetin has the anti-elastase activity, ${ }^{29}$ which is also shown in this study. There is needs further study to screening the responsible compounds which affect the anti-elastase activity of M. malabathricum leaves extracts.

\section{CONCLUSION}

Extraction methods and different concentration of solvents affect the total phenolic and quercetin contents of the extracts. The highest total phenolic content was resulted from defatted process of extraction, while the highest quercetin content was resulted from extraction with $96 \%$ alcohol. M. malabathricum leaves have potential effect as anti-elastase as well as quercetin, but the anti-elastase activity of M. malabathricum leaves is not only due to quercetin.

\section{ACKNOWLEDGEMENT}

This research was supported by Faculty of Pharmacy, Universitas Indonesia and funded by Directorate of Research and Community Engagement (PITTA grant 2017), Universitas Indonesia.

\section{CONFLICT OF INTEREST}

The authors declare no conflict of interest.

\section{ABBREVIATIONS}

70MChE: Defatted macerated 70\% ethanol extract; 70ME: Macerated 70\% ethanol extract; 70RE: Refluxed 70\% ethanol extract; 96MChE: Defatted macerated 96\% ethanol extract; 96ME: Macerated 96\% extract; 96RE: Refluxed 96\% ethanol extract; GAE: Gallic Acid Equivalents; HPLC: High Performance Liquid Chromatography; MCh: Chloroform extact; NE: Neutrophil Elastase; TPC: Total Phenolic Contents.

\section{REFERENCES}

1. Joffry SM, Yob NJ, Rofiee MS, et al. Melastoma malabathricum ( L.) Smith Ethnomedicinal Uses, Chemical Constituents and Pharmacological Properties: A Review. Evidence-based Complement Altern Med. 2012;2012:1-48. doi:10.1155/2012/258434

2. Sirat HM, Susanti D, Ahmad F. Amides, triterpene and flavonoids from the leaves of Melastoma malabathricum L. J Nat Med. 2010;64(4):492-5. doi:10.1007/ s11418-010-0431-8

3. Mamat SS, Kamarolzaman MFF, Yahya F, et al. Methanol Extract of Melastoma malabathricum Leaves Exerted Antioxidant and Liver Protective Activity in Rats. BMC Complement Altern Med. 2013;13(326):1-12.

4. Yasin RAM, Jemon K, Nor NSM. In vivo Irritation Study of Melastoma malabathricum Cream Formulation on ICR Mice. In: AIP Conference Proceeding. 2016;1784(020026):1-6. doi:10.1063/1.4966736

5. Diris MN, Basri AM, Metali F, Ahmad N, Taha H. Phytochemicals and Antimicrobial Activities of Melastoma malabathricum and Melastoma beccarianum Leaf Crude Extracts. Res J Phytochem. 2016;11(1):35-41. doi:10.3923/rjphyto. 2017.35.41
6. Sari A, Linda R, Lovadi I. Pemanfaatan Tumbuhan Obat Pada Masyarakat Suku Dayak Jangkang Tanjung Di Desa Ribau Kecamatan Kapuas Kabupaten Sanggau. J Protobiont. 2015;4(2):1-8.

7. Anshari M, Martiana T, Putra ST, Dyson L. Ethnomedicine of Dayak Paramasan Ethnic in the Meratus Mountains (Part-1): The Medicinal Plants for Diarrhea and Respiratory Disorder. J Appl Enviromental Biol Sci. 2015;5(5):139-47.

8. Mazura MP, Susanti D, Rasadah MA. Anti-inflammatory Action of Components from Melastoma malabathricum. Pharm Biol. 2007;45(5):372-5. doi:10.1080/ 13880200701214797

9. Zakaria ZA, Rofiee MS, Mohamed AM, Teh LK, Salleh MZ. in vitro Antiproliferative and Antioxidant Activities and Total Phenolic Contents of the Extracts of Melastoma malabathricum Leaves. J Acupunct Meridian Stud. 2011;4(4):248-56. doi:10.1016/j.jams.2011.09.016

10. Zakaria ZA, Jaios ES, Omar MH, et al. Antinociception of petroleum ether fraction derived from crude methanol extract of Melastoma malabathricum leaves and its possible mechanisms of action in animal models. BMC Complement Altern Med. 2016;16(1):488. doi:10.1186/s12906-016-1478-1

11. Sunilson AJJ, James J, Thomas J, Jayaraj $P$, Varatharajan $R$, Muthappan $M$ Antibacterial and Wound Healing Activities of Melastoma malabathricum Linn. Afr J Inefct Dis. 2008;2(2):68-73.

12. Nurdiana S, Marziana N. Wound Healing Activities of Melastoma malabathricum Leaves Extract in Sprague Dawley Rats. Int J Pharm Sci Rev Res. 2013;20(2):20-3

13. Sharifi N, Mahernia S, Amanlou M. Comparison of Different Methods in Quercetin Extraction from Leaves of Raphanus sativus L. Pharm Sci. 2017;23(1):59-65. doi:10.15171/PS.2017.09

14. Wilgus TA, Roy S, McDaniel JC. Neutrophils and Wound Repair: Positive Actions and Negative Reactions. Adv Wound Care. 2013;2(7):379-88. doi:10.1089/wound.2012.0383

15. Vasconcelos A, Pêgo AP, Henriques L, Lamghari M, Cavaco-Paulo A. Protein matrices for improved wound healing: Elastase inhibition by a synthetic peptide model. Biomacromolecules. 2010;11(9):2213-20. doi:10.1021/bm100537b

16. Ahmad I, Yanuar A, Mulia K, Mun'im A. Optimization of ionic liquid-based microwave-assisted extraction of polyphenolic content from Peperomia pellucida (L) kunth using response surface methodology. Asian Pac J Trop Biomed. 2017;7(7):660-5. doi:10.1016/j.apjtb.2017.06.010

17. Ang LF, Yam MF, Fung YTT, Kiang PK, Darwin Y. HPLC method for simultaneous quantitative detection of quercetin and curcuminoids in traditional chinese medicines. J Pharmacopuncture. 2014;17(4):36-49. doi:10.3831/KPI.2014.17.035

18. Widyawati PS, Budianta TDW, Kusuma FA, Wijaya EL. Difference of solvent polarity to phytochemical content and antioxidant activity of Pluchea indicia less leaves extracts. Int J Pharmacogn Phytochem Res. 2014;6(4):850-5.

19. Sambandam B, Thiyagarajan D, Ayyaswamy A, Raman P. Extraction and isolation of flavonoid quercetin from the leaves of Trigonella foenum-graecum and their anti-oxidant activity. Int J Pharm Pharm Sci. 2016;8(6):120-4.

20. Adaramola B, Onigbinde A. Effect of Extraction Solvent on the Phenolic Content, Flavonoid Content and Antioxidant Capacity Of Clove Bud. IOSR J Pharm Biol Sci. 2016;11(3):33-8. doi:10.9790/3008-1103013338

21. Santoso J, Anwariyah S, Rumiantin RO, Putri AP, Ukhty N, Yoshie-Stark Y. Phenol Content, Antioxidant Activity and Fibers Profile of Four Tropical Seagrasses from Indonesia. J Coast Develpopment. 2012;15(2):189-96.

22. Michel P, Dobrowolska A, Kicel A, et al. Polyphenolic profile, antioxidant and anti-inflammatory activity of eastern teaberry (Gaultheria procumbens L.) leaf extracts. Molecules. 2014;19(12):20498-520. doi:10.3390/molecules191220498

23. Razmara RS, Daneshfar A, Sahraei R. Solubility of quercetin in water + methanol and water + ethanol from (292.8 to 333.8) K. J Chem Eng Data. 2010;55(9):3934-6. doi:10.1021/je9010757

24. Savic IM, Nikolic VD, Savic-Gajic IM, Nikolic LB, Moder K, Hopkins M. Optimization of Quercetin Extraction from Green Tea ( Camellia sinensis) Using Central Composite Design and the Pharmacological Activity of the Extract. Chem Biochem Eng Q J. 2016;30(1):103-15. doi:10.15255/CABEQ.2015.2166

25. Olszewska M. Separation of quercetin, sexangularetin, kaempferol and isorhamnetin for simultaneous HPLC determination of flavonoid aglycones in inflorescences, leaves and fruits of three Sorbus species. J Pharm Biomed Anal. 2008;48(3):629-35. doi:10.1016/j.jpba.2008.06.004

26. Awang MA, Aziz R, Sarmidi MR, Abdullah LC, Yong PK, Musa NF. Comparison of different solvents on the extraction of Melastoma malabathricum leaves using soxhlet extraction method. Der Pharm Lett. 2017;8(4):153-7.

27. Karupiah S, Ismail Z. Antioxidative effect of Melastoma Malabathticum L Extract and Determination of its Bioactive Flavonoids from Various Location in Malaysia by RP-HPLC with Diode Array Detection. J of App Pharmaceutical Sci. 2013;3(02):19-24. doi:10.7324/JAPS.2013.30204

28. Melzig MF, Pertz HH, Krenn L. Anti-inflammatory and spasmolytic activity of extracts from Droserae Herba. Phytomedicine. 2001;8(3):225-9. doi:10.1078/ 0944-7113-00031

29. Popoola OK, Marnewick JL, Rautenbach F, Ameer F, Iwuoha El, Hussein AA Inhibition of oxidative stress and skin aging-related enzymes by prenylated chalcones and other flavonoids from Helichrysum teretifolium. Molecules. 2015;20(4):7143-55. doi:10.3390/molecules20047143 
GRAPHICAL ABSTRACT

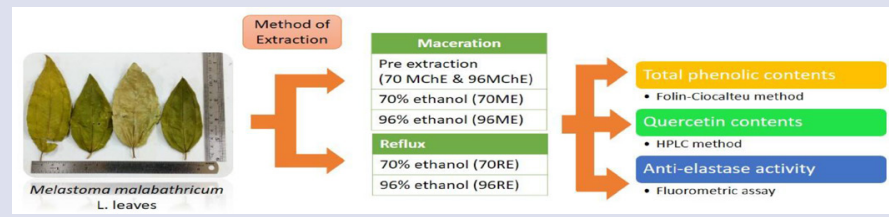

\section{SUMMARY}

- M. malabathricum leaves were extracted with two conventional methods (maceration and reflux) and different ethanol concentration (70\% and 96\%). Leaves were also defatted with chloroform. The highest total phenolic content resulted from the defatted extract, $70 \mathrm{MChE}(222.85 \pm 4.37 \mathrm{mg} \mathrm{GAE} / \mathrm{g})$ and the highest quercetin content resulted from maceration with $96 \%$ ethanol $(96 \mathrm{ME}$, $0.877 \pm 0.034 \% \mathrm{w} / \mathrm{w})$. The highest anti-elastase activity resulted from 70RE with $89.50 \pm 1.53$. There is a weak positive correlation between quercetin and anti-elastase activity, that can be concluded that the activity of $M$. malabathricum is not only due to quercetin.

Cite this article: Amalia T, Saputri FC, Surini S. Total Phenolic Contents, Quercetin Determination and Anti Elastase Activity of Melastoma malabathricum L. Leaves Extract from Different Method of Extractions. Pharmacog J. 2019;11(1):124-8. 